\title{
Comparative Study of Low Tunnel Nursery for Tomato (Solanum lycopersicum L) Seedling Emergence, Growth and Development in under Water Stress Condition
}

\author{
Chanchila Kumari $^{1 *}$, Binit Kumar ${ }^{1}$, Bhoopendera Singh ${ }^{2}$ and Manish Kumar ${ }^{1}$ \\ ${ }^{1}$ ICAR-NRRI-CRURRS-KVK, Koderma, 825109 (Jharkhand), India \\ ${ }^{2}$ ICAR-IISR, Lucknow, 226002 (Uttar Pradesh), India \\ *Corresponding author
}

\begin{abstract}
A B S T R A C T
Keywords

Tomato, Polyhouse,

Low tunnel,

Morphology and

Germination

\section{Article Info}

Accepted:

10 July 2018

Available Online:

10 August 2018

The experiment was deigned to find out the best alternative way to grow healthy tomato seedling under water stress condition. Three different protected and unprotected conditions (Polyhouse, Low tunnel and open field condition) were selected for sowing of seedling. Open field condition was taken up as a control. Production of healthy and vigorous tomato seedling is most important factor in successful commercial production and yield of quality tomato fruits. Moreover, germination of the seed is a critical stage, because the rest of the plant life is directly dependent upon the quality of its germination. Under the observation taken up during development of nursery; the growth of seedling in portray under polyhouse was found significantly superior over all the other treatments on minimum days taken for germination of seedling (5.41 days), Plant height $(6.99 \mathrm{~cm})$, Number of leaf (5.22), Fresh weight (0.92 g) and Dry weight (0.56 g).
\end{abstract}

\section{Introduction}

Tomato (Solanum lycopersicum L.) is a most consumable vegetable crop across the world wide that is widely consumed fresh or processed (Baytown et al., 1994). The increase in area of production and value has increased the economic significance of the crop (Hunter et al., 2012). Several dieticians found that tomatoes and tomato products have numerous health benefits and also contribute to a well-balanced diet. They are a key source of essential nutrients including vitamin A, C and E (Tressen, 1983), providing approximately $20 \mathrm{mg}$ of vitamin C per 100 grams of edible product (Vendrame et al., 2005). The production of healthy and vigorous tomato seedling is most important factor in successful production and yield of tomato fruits.

Germination of the seed is a critical stage, because the rest of the plant life is directly dependent upon the rate of its germination (Qadir and Shahzadi, 1969). Under conservative farming system vegetable producer group mainly grown seedling in open field condition on raised bed soil medium. The major drawbacks of soil nursery are like use of excess amount of water, seeds, fertilizer, 
agrochemicals and implementation of more man power during weeding. Moreover at the time of uprooting of seedlings the root of plant is break, damage as well as some time the plant is damage which is directly give economic losses to the producer (Vendrame et al., 2005). Damaged seedling unable to stand after transplanting and farmers need more seedling for gap filling which may cause extra economic burden to the farmers. Development, management and operations in nursery for development of vigorous, healthy seedling are tough task under semi arid rainfed ecosystem (Vineeta and Agnihotri, 2005). The erratic rainfall and withdrawal condition is one of the most dramatic conditions for the vegetable producer group. Especially in the Jharkhand state 85 percent agricultural practices directly depend on annual rainfall.

But due to global warming, deforestation, Urbanization, maximum use of fuel engine in agricultural work; during the application of machine a large quality of carbon release in atmosphere which is directly affect the climatic condition and excess application of agrochemical similarly gives hazardous impact in environment. Raising of nursery in portray under protected house will play a significant, potential and effective role in the way to minimize the dependency of producer group on rainfall. The technical assistance will be needful for the progressive farmers under the objective of minimizing the application of more agrochemicals, huge quantity of irrigation water, excess use of fertilizer and seeds will be ultimately benefit human as well as an environment. The cycle of seedling production is mainly focused on two stages emergence of seedling from soil medium at time the stage when shoot of the seedling just emerged out from the soil medium surface, and the length of shoot will be at least one $\mathrm{cm}$ besides post emergence is the condition where emergence of seedling from root medium surface (Sugiyama et al., 1996).

\section{Materials and Methods}

The trial was organized in polyhouse of Urwa village, Block Chandwara, District Koderma (Jharkhand). The geographical position of site is $\mathrm{N}^{0} 24.349701$ and $\mathrm{E}^{0} 85.467913$ located besides the Telaiya dam of Koderma. The climatic condition is semi-arid tropic during summer temperature raised up to $42^{0 \mathrm{C}}$ and winter goes a minimum till $5-6^{0 \mathrm{C}}$.

The experiment was designed in cumulative block with three replication of each treatment during Kharif season. The Rohit-2 variety of Samneez Company was used for the experiment. Portray which has 104 block which has a $50 \times 25 \mathrm{~cm}$ of dimension are available were used for seed sowing. Before sowing of seed the soil was sterilized (2\% of formalin) for fifteen days to minimize the population of soil born pathogen in media. In the sixteenth morning sowing was done each block of portray contain one seed (Babik, 1982). Total numbers of 312 seeds were sown in each treatment. Initially all medium was mixed with commercial product of Trichodermaviride @10g per Kilogram of soil medium.

The irrigation of tray was started after one day of sowing and once in a day after germination. The plant nutrient balance mixture of N: P: K was applied after 3 days of sowing @ 15g/15 L of water (Pimpini et al., 1987). The observation recorded for plant height, seedling girth, number of leaves, germination percentage, Fresh and dry weight of seedling from randomizes selected plants. The seed was procured from local available market near by the experimental site. Objectives of the study was laid in two specific output to investigate the effect of different protected condition on tomato seedling growth and to find a suitable medium for raising tomato seedlings in nursery under water stress condition. 
Table.1 Detail of treatment combination

\begin{tabular}{|l|l|}
\hline S. No & \multicolumn{1}{|c}{ Treatments } \\
\hline $\mathrm{T}_{1}$ & Control (Open field condition without portray) \\
\hline $\mathrm{T}_{2}$ & Polyhouse + Portray \\
\hline $\mathrm{T}_{3}$ & Low tunnel + Portray \\
\hline $\mathrm{T}_{4}$ & Open field condition + Portray \\
\hline
\end{tabular}

Table.2 Detail of morphological character of tomato seedling under different condition

\begin{tabular}{|c|c|c|c|c|c|c|}
\hline S. No & Treatments & $\begin{array}{c}\text { Germination } \\
\text { days }\end{array}$ & $\begin{array}{l}\text { Plant height } \\
\text { (cm) }\end{array}$ & $\begin{array}{l}\text { No. of } \\
\text { leaf }\end{array}$ & $\begin{array}{c}\text { Fresh } \\
\text { weight (g) }\end{array}$ & $\begin{array}{c}\text { Dry } \\
\text { weight (g) }\end{array}$ \\
\hline $\mathbf{T}_{1}$ & $\begin{array}{l}\text { Control (Open field } \\
\text { condition without portray) }\end{array}$ & 9.31 & 4.21 & 3.23 & 0.61 & 0.19 \\
\hline $\mathbf{T}_{2}$ & Polyhouse + Portray & 5.41 & 6.99 & 5.22 & 0.92 & 0.56 \\
\hline$\overline{T_{3}}$ & Low tunnel + Portray & 6.30 & 5.64 & 4.81 & 0.88 & 0.43 \\
\hline \multirow[t]{3}{*}{$\mathbf{T}_{4}$} & $\begin{array}{l}\text { Open field condition }+ \\
\text { Portray }\end{array}$ & 7.42 & 5.23 & 3.88 & 0.68 & 0.23 \\
\hline & CV (5\%) & 12.25 & 10.32 & 8.46 & 9.18 & 8.16 \\
\hline & $\mathrm{CD}(5 \%)$ & 2.88 & 1.76 & 1.02 & 0.50 & 0.67 \\
\hline
\end{tabular}




\section{Results and Discussion}

Analysis of variance shows significant difference in that the main polyhouse, low tunnel and open field condition influenced germination, plant height, number of leaf, fresh weight and dry weight of plants.

The maximum germination of seed in minimum days was recorded in polyhouse followed by low tunnel and open field condition. The optimum temperature and relative humidity under protected cultivation play a vital role for germination of seeds.

Moreover, under low tunnel the temperature has been raised more than optimum level because the height of tunnel was very less as compare to optimum.

The presence of insect (Aphid and white fly) may also gave adverse impact after germination of seed. In the open field condition the percentage of soil born disease (damping off) gave adverse effect on pre as well as post germination of seedling. Under favorable condition in polyhouse the growth of plant observed so much significant and gives better option to develop vigorous, healthy and drought tolerant seedling under water stress condition.

Application of mineral mixture (N: P: K) after germination of seed may play an important role in development of more leaf under polyhouse condition. In regards to more healthy plant the fresh and dry weight of plant ultimately gave better results.

\section{References}

Babik, S. (1982) Effect of Pruning and Decapitating on the Earliness of Tomatoes Grown in Heated Plastic
Tunnels. Biuletyn Warzy Wniczy, Poland, 201-212.

Baytown, N., K. Abak, H. Tokgoz, and O. Altunas (1994) Effect of different greenhouse covering materials on inside climate and on the development of tomato plants. Acta Horticulture. 366:125-132.

Emmert, E.M. (1956) Plastic row covering for producing extra-early vegetables outdoors. University of Kentucky Agriculture Extension Services Leaflet 167

Hunter, B., Drost, D., Black B.L., Frisby, J. and R. Ward (2012) Improving growth and productivity of early season high tunnel tomatoes with targeted temperature additions. Horticulture Science. 47(6): 733-740.

Pimpini, F., G. Granguinto, G. Babbo and E. Xodo (1987) The Effect of Protective Structures and of Pinching on the Earliness of Table Tomatoes in the Greenhouse. Protte, 16(8/9):63-73

Qadir SA, Shahzadi HN (1969). Seed germination of common cultivated trees, shrubs and some wild grass. Pakistan Journal Forestry 19:195-220.

Sugiyama, T., S. Iwahoria, and K. Takahashi (1996) Effect of high temperature on fruit setting of Tomato under cover. Acta Horticulture 4:63-69.

Tressen, T., (1983) Polyethylene Mulches in Vegetable Production. 78-008, Ontario, $4 \mathrm{p}$.

Vendrame AW, Maguire I, Moore KK (2005) Growth of selected bedding plants as effected by different by different compost percentages. Florida State Horticulture Society. 18:368-371.

Vineeta M, Agnihotri AK (2005). Source of organic manure. Agrobios. Newsletter, Jodphur, India. 4(7): 11-12. 


\section{How to cite this article:}

Chanchila Kumari, Binit Kumar, Bhoopendera Singh and Manish Kumar. 2018. Comparative Study of Low Tunnel Nursery for Tomato (Solanum lycopersicum L) Seedling Emergence, Growth and Development in under Water Stress Condition. Int.J.Curr.Microbiol.App.Sci. 7(08): 1752-1756. doi: https://doi.org/10.20546/ijcmas.2018.708.200 